\title{
Opportunity for Harmony? Social Empathy of Ahmadi and Sunda Wiwitan Women during Pandemic ${ }^{1}$
}

\begin{abstract}
Siti Aliyuna Pratisti
\{aliyunapratisti@gmail.com\}

PhD Student at Indonesia Consortium for Religious Studies, Universitas Gadjah Mada;

Lecturer in International Relations Department, Universitas Padjadjaran

Abstract. Within these couple months, we are witnessing series of shifting and changing of social landscapes due to the COVID-19 Pandemic. Despite the global experience, there are groups or communities which shaped their perception differently due to their particular dynamics. Women surely have their ideas of COVID-19 which can be differentiated from other sexual identities; even more specific with experiences shared by women in minority groups with a unique set of beliefs and interaction. The selection of particular groups (women in minority group), served as a micro topic to complete a larger frame of joint-research on "Reshaping New Urban Living: Indonesian Women and Coronavirus" conducted by Indonesia Consortium of Religious Studies (ICRS) and Ford Foundation. Social empathy promoted by women will be employed as a theoretical framework to depict whether or not repression to their beliefs affect their social interaction during the pandemic. To do so, an in-depth interview is conducted with women from Jamaah Ahmadi and Sunda Wiwitan as primary informants. A combined observation of social media (by following Whatsapp status, Facebook, and community website) served as a substitute for face to face gestures since this research is conducted during the period of physical distancing in Indonesia (from June to August 2020). Findings will be delivered in the last part of this article which reflects their perception and action of social empathy, also their relation with wider social groups. The scope of this article, however, only limited to discuss the opportunities and challenges of interfaith interaction during Pandemic.
\end{abstract}

Keyword: Religious Harmony, Minority, Social Empathy, Women

\section{INTRODUCTION}

Frame and Objectives

\footnotetext{
${ }^{1}$ This research is a micro part of joint-research of Indonesia Consortium for Religious Studies and Ford Foundation on "Reshaping New Urban Living: Indonesian Women and Coronavirus" conducted by Ida Fitri and Leonard Chrysostomos Epafras in June to August, 2020.
} 
The COVID-19 Pandemic, however sad, has brought hope in unexpected ways. Apart from fear and depression, acts of kindness shown in many parts of the world have shed light for humanity and resilience (Ebuenyi, et al., 2020; Galea, 2020). In Indonesia, West Java is one of the most populated provinces, bears a high risk of contamination and unemployment ${ }^{2}$. However, initiatives to donate food and money for those in need are raised by personal or communities - both in major city such as Bandung or in district areas. Minority groups are among the active campaigner by donating food, daily necessities, also masks and medicine to vulnerable groups impacted by the lockdown policy or losing jobs (Ngadi, 2020). These acts of kindness, though it is common during Pandemic time, give an exceptional meaning to the interfaith interaction in West Java which in the past ten years, showed a high number of intolerance toward minorities ${ }^{3}$.

Above all, there are two incidents which portray the exact picture of intolerance act toward minorities occurred during the period of physical distancing. The first is the closing of Al-Aqsa mosque in Tasikmalaya which belongs to Jemaah Ahmadi (in April 2020) (Suhadi, et. al, 2020); and the second is the closing of Sunda Wiwitan's sacred tomb (in July 2020) (Kompas, 2020). The two incidents provide a basis for informant selection; both for the study of women in minority group by focusing on Jemaah Ahmadi and Sunda Wiwitan women, also for analysing the perception of empathy in social interaction with other groups. This specific topic of social empathy of women in minority groups is aimed to complete a larger frame of research in the title "Reshaping New Urban Living: Indonesian Women and Coronavirus" conducted by Indonesia Consortium of Religious Studies (ICRS) and Ford Foundation.

\section{Women and Social Empathy}

The concept of empathy intersects multiple disciplines, from psychology, social and political sciences, anthropology, neuroscience, to evolutionary science (Hollan \& Throop, 2011). One famous phrase is narrated by Byrock (2013) which quotes Margaret Mead's argument on the act of caring for others, would be initial sign of culture and civilization. A more sociological approach on empathy is provided by Segal (2011) whom defined social empathy as "the ability to more deeply understand people by perceiving or experiencing their life situations and as a result gain insight into structural inequalities and disparities". Segal's definition derived from Burke's depiction on the act of empathy that includes perceiving, understanding, experiencing, and responding the needs of others (Barker, 2003). While pandemic gave the first three acts a contextual setting, the act to responding to the

\footnotetext{
${ }^{2}$ According to 2018 census, the number of working women in West Java reached 444,782. During the lockdown period, the two sectors (factories and entrepreneurship) are most affected as for data from the Dinas Ketenagakerjaan stated that in April 22, 2020, there are 3,396 people experienced layoffs (PHK) and 5,804 others reported being temporarily dismissed (dirumahkan). While in May 1, 2020 (VOA Indonesia, 2020) the number increased significantly to 12,661 people who experienced layoffs and 50,187 workers were dismissed.

${ }^{3}$ During this past decade, West Java's index of religious harmony is below the national average which ranked 32 from 34 Indonesian Provinces (Badan Litbang dan Diklat Kemenag RI, 2019; SETARA Institute, 2018). Conservatism assumed to be the causes of high levels of intolerance: from the closing of religious sites (Ahmadi Mosque, Sacred Site of Sunda Wiwitan also prohibition toward Church Establishment) to the act of violence toward Jamaah Ahmadi and also Syiah. Lanti et.al (2019) traced this trail of conservatism in West Java back to the ideology of Darul Islam/Tentara Islam Indonesia (Islamic State/Indonesia Islamic Soldier) constructed during early independence of Indonesia Republic in 1949. Later on, the movement is banned, but the remnant still found it resonance in today's Islam populism.
} 
circumstances in varied. At least two formed of social responsibility can be observe: in the act of giving donation and by promoting mask and physical distancing (Pfattheicher,et al., 2020).

Pertaining to the correlation of women and empathy, Toussaint and Webb (2005) argued that there are no measures that can validate difference on empathy between genders as different communities showed different pattern of empathy. However, women are likely more open to participate in a group intervention than men, which gave women more sufficient element for perceiving, understanding and experiencing the needs of others (Worthington, et al, 2000). This pattern also occurred in the subjects of this research where women play an eminent role in campaigning social empathy during the pandemic. In Jemaah Ahmadi community, their women's organization known as Lajnah Immailah is taking charge in many social activities (Inasshabihah, 2020), while in Sunda Wiwitan, women also shared the same pattern as inclusive agent in conducting interfaith social responsibilities (Indrawardhana, 2020). However, to limit the scope of discussion, this research will mainly elaborate two questions: (1) how and to whom women in minority group articulate their empathy? and (2) will it lead to better religious harmony? In addition to introduction, the next four sections of this article will elaborate method, result on Jemaah Ahmadi and Sunda Wiwitan Women's experience of Pandemic, discussion on opportunities and challenge for harmony, and the last part, conclusion.

\section{METHOD}

This research applied a qualitative method to narrate social empathy shared by two subjects of women in minority groups, and also to acquire a deep understanding of values, beliefs and perception. While theories of women and social empathy used as the theoretical framework for this research, other insights related to their experiences of the pandemic has provided an understanding of how social empathy shared amongst women. Three sets of informants are interviewed during two months' period (July and August 2020):

Table 1. List of Informants

\begin{tabular}{|l|l|}
\hline $\begin{array}{l}\text { Primary } \\
\text { Informants }\end{array}$ & $\begin{array}{l}\text { Consist of four informants from Lajnah Immaillah and Sunda Wiwitan: BE (60, } \\
\text { a retired midwife, now teach in midwife academic), AR (42, online reseller), SI } \\
(39, \text { housewife) and LR (40, middle school teacher). }\end{array}$ \\
\hline $\begin{array}{l}\text { Focus } \\
\text { Group } \\
\text { Discussion }\end{array}$ & $\begin{array}{l}\text { Various female elements: JAJ, Jakatarub, Sapa Institut, Pasundan Durenbang, } \\
\text { Aisyiah, PEKA Cirebon and Sukabumi discussed Women Condition during } \\
\text { Pandemic in West Java }\end{array}$ \\
\hline $\begin{array}{l}\text { Nuraeni (She for He Resercher, Universitas Padjadjaran), Ira Indrawardana } \\
\text { (Expert and Practitioner of Sunda Wiwitan) and Wawan Gunawan (West Java } \\
\text { Women's Advocacy Network (JAJ) and Jakatarub) }\end{array}$ \\
\hline
\end{tabular}

Source: Database from integrated research of ICRS and Ford Foundation

All of the interview and observation are using an indirect method such as call, online and written interviews due to the health procedure during the pandemic. Social media and community website observation also conducted as substitutes for face to face gesture (as consented by LR and AR). As for the selection of two minorities, groups are based on the incidents of religious intolerance occurred during COVID-19 (toward Ahmadi and Sunda Wiwitan). While for geographical setting, Bandung (the capital city for West Java) and Kuningan (district of West Java which locates Sunda Wiwitan's sacred sites) is selected to 
provide an urban and rural comparison of spatial setting which also shaped women's perception of pandemic experience.

\section{SOCIAL EMPATHY OF JAMAAH AHMADI AND SUNDA WIWITAN WOMEN DURING COVID-19 \\ Women Experience of Pandemic: A Backdrop for Empathy}

In the global frame, women's perception of Pandemic displays more negative experience than positive. Unfortunately, interview with Gunawan (representative of West Java Women's Advocacy Network), also results from FGD on Women Condition during Pandemic in West Java, confirm the similar sense. In West Java, in particular, Gunawan listed problems confronted by women during COVID-19 are as follow: (1) sexual violence; (2) maladministration of social assistance ${ }^{4}$; (3) women with small stalls are forced to close their businesses; (4) the risk of infection due to the minimum understanding of health procedure; (5) there is no sufficient safe house for domestic violence victims; (6) delayed divorce cases lead to the increasing psychological burden; (7) stressed from teaching their children at home without adequate preparation; (8) closing of Pos Pelayanan Terpadu/Posyandu (Integrated Service Post) is affecting the infant health; (9) inconsistent data of women with COVID positive; and (10) unemployment.

In a more specific experience of Jemaah Ahmadi and Sunda Wiwitan, all primary informant confirmed that negative effects outweigh the positive due to the complex problem of decrease income, stressful home environment, and overlapping family and work time which become overwhelming for many. While the positive side of pandemic condition mainly given by informants with active working status (BE and LR), whose both agreed to the fact that pandemic [physical distancing] give them more family time as they feel that 'stay at home' policy gave them more time to spend with their family compared to the pre-pandemic situation. Interestingly, a mother of three who works as an online reseller (AR) also consider that 'stay at home' policy has a positive effect in giving her more time to spend with her children.

In addition to the problems confronted, Nuraeni (She for He Researcher from Universitas Padjadjaran) mentioned that spatial perception and spirituality also set as crucial factors in shaping women's life during the pandemic. The standard policy of social or physical distancing applied all over the world, has disrupted our perception of social and domestic space. Urban communities are likely impacted due to limited space at home-in contrast to rural communities who still have gardens, yards or vast outdoors environment. The sudden changing of space can be stressful for many people. This stressful condition is experienced strongly by SI who has three children with no sufficient room for their activities. SI lived in Bandung, to her outdoor area means a limited porch. Another informant (BE), on the other hand, did not experience such spatial shock due to her home condition which resides in a rural area of West Java. She often posted photos of her daily activities on her Whatsapp status which depict that in a rural area, availability of wide space (garden and plantation), give her relief feeling despite the difficulties on the pandemic. Another vital aspect of women's lives during the pandemic, which is mentioned by Nuraeni, is spirituality-as the feeling of closeness to God provides comfort for a difficult time. For urban women (as SI and LR), expressions of spirituality did not limit to the practices pray or recital the holy book, since they also perceived many ways to express spirituality such as writing in personal website over

\footnotetext{
${ }^{4}$ There are widows who failed to received social assistance because of their name listed under their late husband.
} 
pandemic experience (LR), giving donations and taking care of others (AR and SI) and respect toward nature (BE). These forms of spirituality provide a backdrop for the act of social empathy which will be discussed in the next part of this research.

\section{Experience, Spirituality and Empathy}

Women of Jamaah Ahmadi and Sunda Wiwitan, undoubtedly, are sharing the global experience of the pandemic. They also experienced a changing mode of communication, which also posed as challenged to the two communities. However, there is wide gap experience of using online media between two communities: while Jemaah Ahmadi is used to engaging in online activities, both in religious and social activities (SI and AR provide broad examples such as listening to the Ulama's preach in Youtube, using Zoom for tabligh or even managing community website); Sunda Wiwitan on the other hand, used more limited online media (mainly using Whatsapp) to communicate during lockdown period. BE mentioned that the reluctance on using online media in Sunda Wiwitan communities much related to the daily practices and belief system which rest deeply in the natural interaction both in social and with the environment.

On account of a particular experience, women of Jemaah Ahmadi have communal responsibility that cannot be neglected in any situation. Despite the decrease of income, they have to pay monthly $c a n d a h^{5}$ as a contribution to their community. LR shared an article from Ahmadi forum which explain that although the amount of candah is not fixed (based on the personal capacity to pay), but the payment has certainly become a challenge. According to the community discussion $^{6}$, the pressure in paying candah is coming from personal beliefs not by an outside force, in some writings, misfortune will befall to someone who neglects to pay his candah. This particular experience is unique and shaped internal dynamic, singular to Ahmadi community. The obligation of paying candah in pandemic time raised an internal cohesion to support each other, not only economically, but also psychologically. SI, who also a representative of Lajnah Immaillah in Bandung, confirmed various forms of social sensitivity performed by Lajnah Immaillah including checking the availability of daily necessities and psychological guidance.

But in term of social sensitivity and empathy, Ahmadi has also contributed to public needs regardless of their identities. There were several forms of social activities carried out by Lajnah Immaillah in coordination with other interfaith components such as the National Blood Donor, Humanity First, Palang Merah Indonesia (Indonesia Red Cross) and component from Indonesia military. One of the informant, AR, mentioned that despite the closing of Al-Aqsa Mosque in Tasikmalaya, a social act is performed consistently in many areas of West Java: including Tasikmalaya, Cianjur, also in Bandung. In her Facebook account, AR often shared Lajnah Immaillah social activities (even before COVID-19).

Another particular experience of pandemic came from Sunda Wiwitan Community. The centre of the community is resided in Kenekes, Kuningan, but not restricted to have activities outside their central sacred site. Their belief system has predicted the possibility of a pandemic due to the natural imbalance. According to Indrawardana, for Sunda Wiwitan

\footnotetext{
${ }^{5}$ Chadah is conceived as an allowance for community wealth given by an Ahmadi to the Ahmadiyya Qadian Community as a form of sacrifice for the sake of Islamic advancement, which is managed by Sadr Anjuma Ahmadiyah with a predetermined amount and time (Hasibuan, 2017).

${ }^{6}$ Islamrahmah.id help to provide clear depiction on ahmmadiyah internal discussion on Chandah, specific article mentioned by LR is available in https://islamrahmah.id/meski-susah-tetap-bayar-candahuntuk-raih-ridho-nya/
} 
community in Kuningan, the corona outbreak did not have a direct impact on them as they practice intra-communal activities by living in asceticism inside the Mandala (sacred site)-in other words, they practice social distancing long before the corona outbreak occurred. However, the local customary leader (AKUR) instructs that the community to adhere the health protocol from the government, such as: not accepting visits/groups of people from outside Kanekes during the corona outbreak unless there is a special policy from the local customary apparatus and delay religious ceremony which gathers a massive number of people (Indrawardhana, 2020).

Furthermore, BE, informant from Sunda Wiwitan mentioned her specific experiences that shared only amongst Sunda Wiwitan women who lived in a rural area. First, is the concept of spirituality regarding respect to the environment; and second, the alternative act of social empathy. Their relation to nature becomes an important factor in supporting mental and psychological stability of women during the pandemic. In term of social empathy, the act of donation is collectively initiated by providing food for neighbours who were undergoing independent isolation. This activity is organized by women from the interreligious background and did not limit only to one specific community. When confronted with the incident of the closing of the sacred tomb, $\mathrm{BE}$ stated that it did not change the social relationships amongst different religion and beliefs-the problem lies within the [political] elite perception, BE added. In addition to the act of donation, the community also employ food security system by planting staple foods such as cassava and sweet potatoes to be distributed and given to those in needs. BE, who fortunate enough to have a piece of land, also contribute to the system. The system is instructed by the local customary leader (AKUR) and implemented in many families. This effective system of food security is embedded within their beliefs and close relation to nature, which provide another singular experience of the pandemic. These portrait of social empathy from minority resonate to Baker's depiction of empathy that includes perceiving, understanding, experiencing, and responding to the needs of others. The social empathy showed by Jemaah Ahmadi also Sunda Wiwitan women have given for religious harmony in West Java-especially in time of the pandemic.

\section{SOCIAL EMPATHY: AN OPPORTUNITY FOR HARMONY?}

A bitter history of minority is recorded in Indonesian's interreligious journey. As Trianita (2012) stated that being women and Ahmadi in Indonesia means facing two layer of oppression. The community of Sunda Wiwitan also faced similar struggle of acceptance before it legally stated as a recognized belief system in Indonesia. This relation is worsened by existing dichotomy of majority versus minority. Maliki (2010) argued that the term 'minority' is prone to be the target of labelling, a form of discrimination committed by one group against another group-usually by the dominant majority against the minority. The goal is marginalization and even emphasis on minority groups fall victim to this labelling. In the realm of identity politics, labelling and marginalization is deliberately constructed to maintain the power of dominant-majority.

In contrast to the contending narrative of majority vis a vis minority, social empathy is built based on positive social interaction between communities (Segal, 2011)-which hardly found in the setting of conflictual identity narratives. Segal's three elements of social empathy-perceiving, understanding, and experiencing-are likely absent, therefore the act to correspond to the needs of others is also likely to be lacking. However, the wall of indifference is torn down by the spreading of coronavirus in early 2020. Since then, the impact of the pandemic has devastated many lives as the tragedy experienced on a global scale. An unexpected turn in social relation occurred, particularly in Indonesia, when pandemic 
reshaping the relation between minority and majority-at least in the form of social empathy. Social act and sensitivity is given regardless of their identity as pandemic given a contextual pushing factor for perceiving, understanding, and experiencing. In a more substantial level, freedom to express religious identity will lead to wider acceptance and integration.

In reality, it is too early to acclaim a wide social acceptance toward minority in Indonesia. During the process of this research, a closing of the Sunda Wiwitan site as instructed by the Kuningan government. And there is no guarantee that Jamaah Ahmadi will be free from oppression in the future. Prior to the pandemic, there were efforts to build a positive social relation between religious groups initiated by local non-governmental organizations (such as Jakatarub) with support from mainstream religious organization such as Nahdatul Ulama and Muhammadiyah. However, the efforts are fruitless without direct involvement and support from the public and government. As the result, in 2019, West Java still considered hostile to religious minorities. But the gesture of empathy shared during a pandemic can be taken as the first step for harmony. As mentioned by Pfattheicher, et al. (2020), that the relation of empathy is one of the keys in understanding the changing social landscape during a pandemic; a time when people are sharing the same language of social sensitivity.

\section{CONCLUSION}

Pandemic has reshaped many lives-including social relations. Women, despite confronted by various challenges, has become a key player of empathy and social sensitivity. For Jemaah Ahmadi and Sunda Wiwitan women, however, the experience of pandemic and gestures of social sensitivity did not guarantee them with a deliberate form of social harmony; as incidents of intolerance to both groups still occurred even during COVID-19. Despite the bleak condition of pandemic and intolerance, there is a sign of hope from women of Jemaah Ahmadi and Sunda Wiwitan which actively performed as an inclusive agent. In many parts of West Java, gestures of sensitivity showed by Jemaah Ahmadi women, has shaped positive social relation with wider groups-even after the incident of closing of Ahmadi mosques during COVID-19. In a similar vein, Sunda Wiwitan women also performed the role of inclusive agent when they respond cooperatively to the health protocol, respect the instruction from the local authority (despite the incident of closing the sacred tomb), and actively contribute to the interfaith social action. Therefore, women from the two communities offered a particular view and experience of the pandemic which based on two specific conditions: (1) their belief system and their religious practices; and (2) their role as inclusive agent. While the previous gave way to internal cohesion and an alternative act of social empathy, the latter allowed hope in reshaping the interreligious relation in Indonesia toward harmony and wider acceptance of differences.

\section{ABOUT THE AUTHOR}

Siti Aliyuna Pratisti is currently enrolled as Ph.D student in Indonesia Consortium for Religious Studies. A lecturer in International Relations Department of Univeritas Padjadjaran with specific interest on identity studies while managing and writing an independent media of arts and politics (antimateri.com). 


\section{Statement of Funding}

This research is a micro part of joint-research of Indonesia Consortium for Religious Studies and Ford Foundation on "Reshaping New Urban Living: Indonesian Women and Coronavirus" conducted by Ida Fitri and Leonard Chrysostomos Epafras, 2020. Also many thanks to informants who are willing to share their insights and experiences on the hard-time of pandemic COVID-19

\section{REFERENCES}

Badan Litbang dan Diklat. (2019). Indeks Kerukukunan Umat Beragama. Kementrian Agama RI Barker, R. L. (2003). The Social Work Dictionary. Washington DC: NASW Press.

BPS. (2019). Laporan Sensus Penduduk Jawa Barat. Badan Pusat Statistik Jawa Barat

Byock, I. (2013). The Best Care Possible: A Physician's Quest to Transform Care Through the End of Life. New York: Avery.

Ebuenyi, I., Smith, E., Holloway, E. Jensen, R., D’Arino, L., Maclaclhan, M. (2020). COVID-19 as Social Disability: The Opportunity of Social Empathy for Empowerment. Global Health, 5(8).

Galea, S. (2020). Compassion in a Time of COVID-19. Public Health Emergency Innitiatives, 395(10241), 1897-1898.

Hollan, D., \& Throop, C. (Eds. ). (2011). The Anthropology of Empathy: Experiencing the Lives of Others in Pacific Societies. Berghahn Books.

Inasshabihah. (2020). Perempuan Ahmadiyah Memberdayakan Diri Menghadapi Intoleransi. Studi Agama Dan Lintas Budaya. https://crcs.ugm.ac.id/perempuan-ahmadiyah-memberdayakan-dirimenghadapi-intoleransi/

Indrawardhana, I. (2020). Kesiapan Agama untuk Normal Baru. Presented in Webinar of Religion and COVID-19, FISIP Universitas Jendral Soedirman

Kompas. (2020). Makam Sesepuh Sunda Wiwitan Disegel, Dianggap Tugu dan Akan Dibongkar Jika Tak Berizin. https://regional.kompas.com/read/2020/07/22/06160021/makam-sesepuh-sundawiwitan-disegel-dianggap-tugu-dan-akan-dibongkar-jika?page=all

Maliki, D. W. (2010). Resistensi Kelompok Minoritas Keagamaan Jemaat Ahmadiyah Indonesia. Jurnal Ilmu Sosial Dan Ilmu Politik, 14(1), 47-62.

Ngadi. (2020). Jumlah pekerja yang terdampak Covid.

Pfattheicher, S., Nockur, L., Böhm, R., Sassenrath, C., Petersen, M. B. (2020). The Emotional Path to Action: Empathy Promotes Physical Distancing and Wearing Face asks during the COVID-19 Pandemic.

SETARA Institute. (2018). Indeks Kota Toleran Tahun 2018. https://setara-institute.org/indeks-kotatoleran-tahun-2018/

Segal, E. A. (2011). Social Empathy: A Model Built on Empathy, Contextual Understanding, and Social Responsibility That Promotes Social Justice,. Journal of Social Service Research, 37(3), 266-277.

Suhadi, Zainal Abidin Bagir, Renata Arianingtyas, A. (2020). Pembatasan Hak Beragama di Masa Wabah COVID-19. Yogyakarta: Program Studi Agama dan Lintas Budaya

Toussaint, L. \& J. R. W. (2005). Gender Differences in the Relationship between Empathy and Forgiveness. Journal of Social Psychology, 145(6), 673-685.

Trianita, W. (2012). "Sacrifice" Among Ahmadi Women. Indo-Islamika, 2(1), 59-73.

Worthington, E.L, Sandage, S.J, Berry, J. . (2000). Group Interventions to Promote Forgiveness and Empathy. In T. C. . McCullough M.E, Pargament K.I (Ed.), Forgiveness: Theory, Research, and Practice (pp. 228-253). Guilford. 